\title{
Note
}

\section{Facile water mediated chemo-selective synthesis of anilines from nitroarenes using triethylammonium formate}

\author{
M B Sridhara, G R Srinivasa \& D Channe Gowda* \\ Department of Studies in Chemistry, University of Mysore, \\ Manasagangotri, Mysore 570 006, India \\ Email:dcgowda@yahoo.com
}

Received 2 May 2005; accepted (revised) 13 June 2005

A simple and efficient protocol for the chemo-selective reduction of substituted nitroarenes to corresponding anilines in good yields using inexpensive commercial zinc dust and triethylammonium formate in water at ambient temperature and pressure is established. Many other reducible functional groups like methoxy, methyl, ester, nitrile, amide, acid, phenol and halogens are unaltered with the present systems.

Keywords: Chemo-selective reduction, nitroarenes, zinc dust, triethylammonium formate, ambient temperature, functional groups

\section{IPC: Int.Cl. ${ }^{8} \mathrm{C} 07 \mathrm{C}$}

With the increasing environmental concerns and the regulatory constraints faced in the chemical and pharmaceutical industries, development of environmentally benign organic reactions has become a crucial and demanding research area in modern organic chemical research ${ }^{1}$. Organic synthesis in water not only represents a new technology with minimum waste problems, but also a new methodology since the properties of water can be used to manipulate the reactivity of organic compounds. Replacing organic solvents with water offers economic advantages, improves safety and in combination with the development of catalytic processes offers great opportunities for green chemistry $^{2}$. Reduction in an aqueous media will contribute to a most convenient and useful method because an aqueous medium as a solvent for organic reactions has many advantages, from the view point of cost, safety, easy handling and the environment, in comparison to the use of an organic solvent. Recently, in view of environmental concerns, organic reactions in only water with no organic solvents are receiving great attention.

Reduction of nitroarenes to anilines is an important transformation since many anilines exhibit biological activities and find a multitude industrial applications, being important intermediates in the synthesis of chemicals such as dyes, antioxidants, photographic, pharmaceutical and agricultural chemicals ${ }^{3}$. Furthermore, the anilines are easily converted into diazonium salts, which can be substituted for many other functional groups. There are a variety of methods for the reduction of nitroarenes reported in the literature; the most popular being catalytic hydrogenation ${ }^{4.5}$, metal-mediated reduction ${ }^{6}$, dissolving metal reduction ${ }^{7,8}$ and catalytic transfer hydrogenation". However, these methods require expensive, moisture sensitive reagents and organic solvents. Since the conventional reductions of nitroarenes using zinc metal require an organic solvent, corrosive reagents such as $\mathrm{NH}_{3}$, conc. $\mathrm{HCl}$, or $20 \%$ aq. $\mathrm{NaOH}$, it is difficult to contend that these methods are environmentally harmonious. Recently, reduction of organic compounds in an aqueous medium at high temperature was reviwed ${ }^{10}$. Poliakoff reported a selective reduction of nitroarenes to anilines using metallic zinc in water at $250{ }^{\circ} \mathrm{C}$ (near critical water) in high yields ${ }^{11}$. Another method of reduction of nitroarenes to amines by employing 7.25 equivalent of zinc in presence of $\mathrm{NH}_{4} \mathrm{Cl}$ at $80^{\circ} \mathrm{C}$ was reported $^{2}$. More recently, metallic iron nanoparticles catalysed reductions of aromatic nitro compound to the corresponding amino derivatives have also been explored $^{12}$. However, these reactions require high temperature and prolonged reaction time periods.

In this communication, we wish to describe a simple and convenient method for the catalytic hydrogen transfer reduction of substituted nitroarenes to corresponding anilines by using readily available inexpensive commercial zinc dust and triethylammonium formate as hydrogen donor under ambient temperature and pressure in water, as depicted in Scheme I.

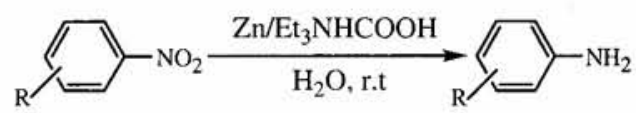

$\mathrm{R}=\mathrm{OH}, \mathrm{CH}_{3}, \mathrm{OCH}_{3}, \mathrm{COOH}, \mathrm{COCH}_{3}, \mathrm{COOR}, \mathrm{CONH}_{2}$ and halogens 
All the substituted nitroarenes were easily reduced to their corresponding anilines by using triethylammonium formate and commercial zinc dust in water at ambient temperature and pressure without any organic solvent. As seen from Table I reduction of 4-nitroacetophenone, 4-nitrophenyl acetonitrile and 4-nitrobenzoic acids gave the corresponding anilines without affecting the other reducible groups. Even the reduction of chloronitrobenzene showed high selectivity for chloroanilines without any

Table I-Reduction of substituted nitroarenes to anilines with triethylammonium formate catalyzed by commercial zinc dust in water ${ }^{3}$

Entry Nitroarenes

1<smiles>O=[N+]([O-])c1ccccc1</smiles>

2

3<smiles>Cc1ccccc1[N+](=O)[O-]</smiles>

4<smiles>O=[N+]([O-])c1ccc(-c2ccccc2)cc1</smiles>

5<smiles>O=[N+]([O-])c1ccc2ccccc2c1</smiles>

6<smiles>O=[N+]([O-])c1c(O)ccc2ccccc12</smiles>

7

8

9

10

11

12

13

14

15<smiles>Nc1ccc([N+](=O)[O-])cc1</smiles><smiles>NC(=O)c1ccc([N+](=O)[O-])cc1</smiles><smiles>CC(=O)c1ccc([N+](=O)[O-])cc1</smiles><smiles>N#Cc1ccc([N+](=O)[O-])cc1</smiles><smiles>O=[N+]([O-])c1ccccc1Cl</smiles><smiles>O=[N+]([O-])c1ccc(Br)cc1</smiles><smiles>O=[N+]([O-])c1ccc(O)cc1</smiles>

Time
(min)<smiles>N#CCc1ccc([N+](=O)[O-])cc1</smiles>

10

8

8

8

6

8<smiles>Nc1c(O)ccc2ccccc12</smiles>

5

Amines

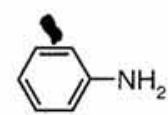<smiles>N#Cc1ccc(N)cc1</smiles><smiles>Cc1ccccc1N</smiles><smiles>Nc1ccc(-c2ccccc2)cc1</smiles>

90

88<smiles>COc1ccc(N)cc1</smiles>

4

8

8

10

5

6

5

7<smiles>Nc1ccccc1Cl</smiles><smiles>Nc1ccc(N)cc1</smiles><smiles>NC(=O)c1ccc(N)cc1</smiles><smiles>CC(=O)c1ccc(N)cc1</smiles><smiles>Nc1ccc(C(=O)O)cc1</smiles>

80

$90^{\circ}$

90

90

90

80

90<smiles>Nc1ccc(Br)cc1</smiles><smiles>Nc1ccc(O)cc1</smiles>

88 m.p ${ }^{\circ} \mathrm{C}$

Found(Lit).

$182-85(184-86)^{17}$

$84-85(83-85)^{17}$

$200-02(200-202)^{18}$

$135-37(137)^{17}$

$111-13(113)^{17}$

$204-07(206)^{17}$

$103-05(106)^{18}$

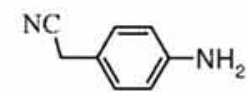

$183-85(186)^{18}$

$184-87(186)^{17}$

$107-09(108)^{18}$

$66-67(66)^{18}$

$45-47(45-48)^{17}$

${ }^{a}$ All of the products are known and the isolated products gave IR spectra in agreement with their structures. ' Isolated yields are based on single experiment and the yields were not optimized; ${ }^{\mathrm{c}}$ Boiling point. 
dehalogenation of chloronitrobenzene. It is worth noting that all the substituted nitroarenes reduced by this system were obtained in good yields $(80-90 \%)$ without any chromatographic separation. The reactions are extremely easy to carry out and are usually complete within 4 to $10 \mathrm{~min}$. The course of reaction was monitored by TLC and IR spectra. The work-up and isolation of the products were easy. All the products were characterized by comparison with authentic samples (TLC, IR, ${ }^{1} \mathrm{H}$ NMR and m.p.). A control experiment, using substituted nitroarenes with triethylammonium formate but without zinc dust, did not yield the desired product. Furthermore, an attempted reduction of a substituted nitroarenes using zinc dust in the absence of triethylammonium formate gave $20 \%$ of amino compounds, if the reaction mixture was stirred for more than $24 \mathrm{hr}$.

Water mediated chemo-selective reduction of substituted nitroarenes to anilines with triethylammonium formate and commercial zinc dust system has significant advantages over earlier $\mathrm{Et}_{3} \mathrm{NHCO}_{2} \mathrm{H} / 10 \% \mathrm{Pd} / \mathrm{C}$ (ref. 13), $\mathrm{Zn} / \mathrm{CaCl}_{2} / \mathrm{EtOH}$ (ref. 14), $\mathrm{Zn} / \mathrm{H}_{2} \mathrm{O}$ at $250^{\circ} \mathrm{C}$ (ref. 11 ), $\mathrm{Fe} / \mathrm{H}_{2} \mathrm{O}$ at $210^{\circ} \mathrm{C}$ (ref. 12), $\mathrm{Fe}\left(\mathrm{NO}_{3}\right)_{3} .9 \mathrm{H}_{2} \mathrm{O}, \mathrm{FeSO}_{4} \cdot 7 \mathrm{H}_{2} \mathrm{O}, \mathrm{Fe}(\mathrm{acac})_{3}$ and ferrocenc at $150^{\circ} \mathrm{C}$ (ref. 14 ), $\mathrm{Zn} / \mathrm{NH}_{4} \mathrm{Cl}$ at $80^{\circ} \mathrm{C}$ (ref, 2), $\mathrm{Zn} / \mathrm{NH}_{4} \mathrm{Cl},[\mathrm{bmim}]\left[\mathrm{PF}_{6}\right]: \mathrm{H}_{2} \mathrm{O}$ (ref. 3), and $\mathrm{Zn} / \mathrm{HCO}_{2} \mathrm{NH}_{4}$, [bmim] $\left[\mathrm{BF}_{4}\right]: \mathrm{H}_{2} \mathrm{O}$ (ref. 3) and equally compatible with the systems like $\mathrm{HCOONH}_{4} / \mathrm{Zn}$ (ref. 16). In this reduction process, water, apart from being a green solvent, effectively controls the rate of the reaction and hence exothermicity. The limited solubility of the substrate in water maintains sufficient productivity and also prevents reaction runaway. This is an additional advantage since reduction of nitroarenes is highly exothermic. Due to the use of the zinc catalyst, organic solvents can be totally avoided, thereby making the process more eco-friendly.

In conclusion, the obvious advantages of proposed method are its simple operation, the milder reaction conditions, easy product isolation and prevention of unwanted by-products such as, hydroxylamine, nitroso, hydrazo, and azo compounds. The catalyst is non-pyrophoric in nature and another interesting behavior of $\mathrm{Zn}$ dust lies in the fact that it can be recycled after simple washing with $\mathrm{Et}_{2} \mathrm{O}$ and dil $\mathrm{HCl}$, thus rendering the process more economic. The present method offers an economical, safe, and environmentally benign alternative to available procedures.

\section{Experimental Section}

General. ${ }^{1} \mathrm{H}$ NMR spectra were recorded on an AMX-400 MHz spectrometer using $\mathrm{CDCl}_{3}$ as the solvent and TMS as internal standard; and IR spectra on a Shimadzu FTIR-8300 spectrometer. The melting points were determined by using Thomas-Hoover melting point apparatus and are uncorrected. TLC was carried out on silica gel plates obtained from Whatman Inc. The substrates were either commercial products and were used as purchased or were prepared according to literature procedures. Zinc dust (particle size $<45 \mu \mathrm{m}$ ) was purchased from E-Merck Mumbai (India) Ltd, Mumbai. The triethylammonium formate was prepared by neutralizing slowly, equal moles of triethylamine and formic acid in an ice water-bath with constant stirring. The resulting triethylammonium formate solution was used as such in all reactions. All of the solvents used were of analytical grade or were purified according to standard procedures.

Synthesis of anilines. General procedure. A suspension of nitroarene (10 mmoles) and commercial zinc dust (10 mmoles) in water $(15 \mathrm{~mL})$ was stirred with triethylammonium formate ( 20 mmoles) at room temperature. The reaction was exothermic. After completion of the reaction (monitored by TLC), the product was extracted with $\mathrm{Et}_{2} \mathrm{O}$ or $\mathrm{CH}_{2} \mathrm{Cl}_{2}(2 \times 30$ $\mathrm{mL}$ ). The extract was washed twice with saturated sodium chloride solution $(30 \mathrm{~mL})$ and then with water $(30 \mathrm{~mL})$. The organic layer was dried with anhydrous $\mathrm{Na}_{2} \mathrm{SO}_{4}$ and the solvent was evaporated under reduced pressure to obtain the desired amino compounds.

\section{Acknowledgement}

Authors gratefully acknowledge financial support from the UGC, New Delhi. One of authors (MBS) is also thankful to the University of Mysore, Mysore for research fellowship.

\section{References}

1 Anastas P \& Williamson T, Green Chemistry: Frontiers in Benign Chemical Synthesis and Processes, (Oxford, New York), 1998, p 360.

2 Tsukinoki T \& Tsuzuki H, Green Chem, 3, 2001, 37.

3 Khan F A, Dash J, Sudheer C \& Gupta R K, Tetrahedron Lett, 44, 2003, 7783.

4 Rylander P N, Hydrogenation Methods, (Academic Press, New York), 1985, p 365.

5 House H O, Modern Synthetic Reactions, 2 Edn, (Benzamin Inc., USA), 1977, p 145.

6 Banik B K, Mukhopadhyay C, Venkataman M S \& Becker F F, Tetrahedron Lett, 39, 1998, 7243. 
7 Merlic C A, Motamed S \& Quinn B, J Org Chem, 60, 1995 , 3365.

8 Doxsee K M, Feigel M, Stewart K D, Canary J W, Knobler C B \& Cram D J, J Am Chem Soc, 109, 1987, 3098.

9 Johnson R A W, Wilby A H \& Entwistle I D, Chem Rev, 85, $1985,129$.

10 Katrizky A R, Nichols D A, Siskin M, Murugan R \& Balasubramanian M, Chem Rev, 101, 2001, 837.

11 Boix C \& Poliakoff M, J Chem Soc, Perkin Trans, 1, 1999, 1487.
12 Wang L, Li P, Wu Z, Yan J, Wang M \& Ding Y, Synthesis, 2003, 2001.

13 Cortese N A \& Heck R F, J Org Chem, 42, 1977, 3491.

14 Shundbcry R \& Pitts W, J Org Chem, 56, 1991, 3048.

15 Deshpande R M, Mahajan A N, Diwakar M M, Ozarde P S \& Chaudhari R V, J Org Chem, 69, 2004, 4835.

16 Gowda D C, Mahesha B \& Gowda S, Indian J Chem, , 40B, 2001, 75 .

17 Vogel A I, Text Book of Practical Organic Chemistry, $5^{\text {th }}$ Edn, (Addison Wesley Longman Limited, UK), 1997.

18 The Merck Index, $11^{\text {th }}$ Edn, (Merck \& Co., Inc., USA), 1989. 